Editorial

\title{
Fuels-An International and Interdisciplinary Scientific Open Access Journal
}

\author{
Fuels Editorial Office
}

MDPI, St. Alban-Anlage 66, 4052 Basel, Switzerland; fuels@mdpi.com

Received: 13 July 2020; Accepted: 16 July 2020; Published: 17 July 2020

Fuels are deeply entrenched in every aspect of our daily life. They are closely related to energy, the environment, and pollution. We would like to introduce an advanced platform for scientists and engineers all over the world to share, promote, and disseminate their research innovations in the field of fuel characterization, processing, and technology. It is, thus, our pleasure to announce the launch of Fuels (ISSN 2673-3994), a scholarly, peer-reviewed open access journal with the work of a team of dedicated editors and carefully chosen external reviewers.

Fuels publishes papers covering a wide variety of fuels including, but not limited to:

- $\quad$ Solid Fuels: wood, charcoal, biomass, coal, peat, coke, and solid waste;

- Liquid Fuels: petroleum, liquefied natural gas, liquefied petroleum gases, biofuel, alcohols, and liquefied hydrogen;

- Gaseous Fuels: natural gas, shale gas, coal-bed methane, water gas, syngas, biogas, and blast furnace gas;

- $\quad$ Others Related Areas: fuel cells, solar fuels, carbon capture and storage, etc.

This journal publishes original research, review articles, and short communications on all areas of fuel science and technology in a timely manner. There is no restriction on the length of the papers, and full details (experimental, modeling, or otherwise) must be provided so that the results can be replicated.

We welcome you to Fuels and invite you to contribute your papers or submit Special Issue proposals. We look forward to receiving your very best manuscripts for publication in this journal. 